\title{
ODHAD HUSTOTY KŮRY A GLOBÁLNÍHO GRAVITAČNÍHO POLE MĚSÍCE Z DAT DRUŽICOVÉ MISE GRAIL A SENZORU LOLA
}

\author{
CRUSTAL DENSITY AND GLOBAL GRAVITATIONAL FIELD ESTIMATION OF THE \\ MOON FROM GRAIL AND LOLA SATELLITE DATA
}

\author{
Michal Šprlák ${ }^{1}$, Shin-Chan Han², Will Featherstone ${ }^{3}$, Pavel Novák ${ }^{4}$, \\ Martin Pitoňák
}

\begin{abstract}
Abstrakt
V tejto štúdií používame Newtonov integrál $\mathrm{v}$ spektrálnej oblasti na riešenie dvoch geodetických/geofyzikálnych úloh pre Mesiac, vid' [1]. V prvej úlohe odhadneme hustotu mesačnej kôry (inverzný problém). Využivame model gravitačného pol'a GL1500E určený družicovou misiou GRAIL a topografiu zo senzora LOLA na odhad: 1) konštantnej, 2) laterálne premenlivej a 3) priestorovo premenlivej hustoty mesačnej kôry. V druhej úlohe vypočítame modely mesačného gravitačného pol'a odvodené z týchto troch zložení mesačnej kôry (priamy problém) do stupňa 2519 (zodpovedajúceho priestorovému rozlíšeniu 2,2 km na rovníku). Nakoniec testujeme naše nové modely, ako aj najnovšie a nezávislé priame modely gravitačného pol'a, s oficiálnymi produktami družicovej misie GRAIL úrovne 1B a úrovne 2. Naše globálne modely gravitačného pol’a s vysokým rozlíšením budú prínosom pre budúcu navigáciu mesačných sond a geofyzikálny prieskum Mesiaca.
\end{abstract}

\begin{abstract}
We employ Newton's integral in the spectral domain to solve two geodetic/geophysical tasks for the Moon, see [1]. Firstly, we determine density distribution within the lunar crust (inverse problem). For this purpose, we exploit GL1500E GRAIL gravitational field model and LOLA topography to estimate: 1) constant, 2) laterally variable, and 3) 3D spatially variable crustal density. Secondly, we calculate lunar gravitational field models inferred by these three crustal compositions (forward problem) up to spherical harmonic degree 2519 (corresponding to a spatial resolution of $2.2 \mathrm{~km}$ at the lunar equator). We test the performance of our new models, and of recent and independent forward models, against the official Level 1B and Level 2 GRAIL products. Our high resolution global gravitational field models will be an asset to future lunar lander navigation and geophysical exploration of the Moon.
\end{abstract}

\section{Klíčová slova}

Newtonov integrál, Priame modelovanie, LOLA, GRAIL, Objemová hustota, Kôra

\footnotetext{
${ }^{1}$ Michal Šprlák, doc., Ing., Ph.D., NTIS - Nové technologie pro informační společnost, Fakulta aplikovaných věd, Západočeská univerzita v Plzni, Technická 8, 30100 Plzeň, e-mail: michal.sprlak@gmail.com

${ }^{2}$ Shin-Chan Han, Dr., Prof., School of Engineering, Faculty of Engineering and Built Environment, University of Newcastle, University Drive, Callaghan, NSW 2308, Australia

${ }^{3}$ Will Featherstone, Dr., Prof., School of Earth and Planetary Sciences, Curtin University of Technology, GPO Box U1987, Perth, WA, 6845, Australia

${ }^{4}$ Pavel Novák, prof., Ing., Ph.D., NTIS - Nové technologie pro informační společnost, Fakulta aplikovaných věd, Západočeská univerzita v Plzni, Technická 8, 30100 Plzeň

${ }^{5}$ Martin Pitoňák, Ing., Ph.D., NTIS - Nové technologie pro informační společnost, Fakulta aplikovaných věd, Západočeská univerzita v Plzni, Technická 8, 30100 Plzeň
} 


\section{Keywords}

Newton's integral, Forward modelling, LOLA, GRAIL, Bulk density, Crust

\section{Literatura}

[1] Šprlák, M., Han, S-C, Featherstone, W. (2020) Crustal Density and Global Gravitational Field Estimation of the Moon from GRAIL and LOLA Satellite Data. Planetary and Space Science 192:105032. doi: https://doi.org/10.1016/j.pss.2020.105032. 